\title{
TRANSLATION STRATEGIES OF THE UKRAINIAN MILITARY TERMINOLOGY ON THE BASIS OF ENGLISH MEDIA DISCOURSE
}

\author{
A. V. Prokopenko, PhD in Philology, assistant professor \\ ID ORCID: https://orcid.org/0000-0002-4590-4201 \\ I. Chuprina, student \\ Sumy State University, \\ 2, Rymskoho-Korsakova St, Sumy, 40007, Ukraine \\ E-mail: a.prokopenko@gf.sumdu.edu.ua; irinacuprina17@gmail.com
}

The article deals with the translation of Ukrainian military terminology on the basis of English media discourse. Military sublanguage continues to exist in a certain historical period of the country, simultaneously is subjected to the laws of evolutionary development. Its core, that is terminology and periphery, is replenished by "neologisms», that is, words, idioms, appeared at a certain stage of development of the military sublanguage for transferring of a new military realities and concepts. While investigating journalistic texts, it becomes obvious that the choice of the translation method of military terminology directly depends on the structure of the term itself. The results of the research prove that the most widespread and popular methods of translation of simple and multicomponent (complex) terms are lexical and semantic substitutions, descriptive translation, and calculating. In the process of translating abbreviations, the most frequently used prisms are the translation of the full form, as well as semantic substitutions, transcription and transliteration.

Key words: military terminology, descriptive translation, abbreviations, transcription, transliteration, substitution.

https://doi.org/10.21272/Ftrk.2018.10(4)-8

Introduction. Military translation is a separate linguistic discipline due to the high requirements for the quality and accuracy of translation, errors in which at best lead to arbitrary and subjective interpretation of the text and misunderstandings during the negotiations; the worst can cost someone a life or entail serious material costs. It requires irreproachable foreign military terminology proficiency as well as an adequate Ukrainian military terminology proficiency, which is regularly replenished through the introduction of new types of weapons, innovations in the field of materials and equipment, the emergence of new strategies and methods of combat. Military translation covers all types and methods of translation, from the translation of charters and documents to interpretation in the course of radio exchange, not excluding two-way transfer when talking on military topics.

The military conflict in which our country is located forms the image of Ukraine within the limits of military terminology, which also describes economic hardships, through the parallels between soldiers fighting in the war with terrorists, and ordinary people who are struggling with rising prices, falling incomes and job losses. The linguistic-dominant image reveals the interrelationships between language and society, language and ideology, language and military situation in the country.

The problems of military translation appeared in the focus of research of Russian translators A. D. Schweizer, L. L. Neulubin, O. A. Dormidontova, R. K. MinyarBeloruchyev, N. N. Denisov, N. K. Garbovskii, G. M. Strelkovsky, O. Vasilchenko, G. A. Sudzilovsky, whose works have made a significant contribution to the theory and practice of translation. However, in Ukraine, the works devoted to military translation are not numerous and have methodical nature (V. Balabin, V. I. Gaponov).

(C) Prokopenko A. V., Chuprina I., 2018 
The relevance of the study is that the importance of correct communications in military affairs never diminished especially now, when the processes of globalization go incredibly intensely, and military all the world has to communicate daily with each other. The correct translation of military literature, letters, and dialogues - is a pledge of peaceful coexistence of all countries in the world. The objective of the research is to describe lexical peculiarities and translation methods of Ukrainian military terms into English.

The tasks of this research are as follows:

1) Consider approaches to understanding the terms in the lexicology system;

2) To study approaches to the terms translation in general;

3) To study the military terms and the scope of their usage;

4) To give the structural-semantic characteristics of the military terminology;

5) Consider the methods of transferring military terms from Ukrainian into English.

The object of the research is military terms used in English and Ukrainian terminology and its subject - translation strategies of the military terminology.

The methods of the research are:

1) the method of generalization is applied for determining the main features of the use of military terms;

2) the descriptive method - for describing the key features of the military an in the process of their translation;

3) the method of comparison - for the analysis of translation methods of abbreviations, thus, it is determined which method is used most often.

Results of the research: One of the main ways of expressing language knowledge are terms that are created in order to become means of communication in the process of professional and scientific activity and to optimize the development of human cognition. Military vocabulary includes a special layer of lexical units, because it serves a special branch of human activity - the organization of the armed forces, operational-tactical art, weapons etc. Military vocabulary can be common and speak a means of socio-speech characteristics. As part of military vocabulary, we distinguish military terms and military vocabulary. Military terms are words or phrases that correspond to the concepts of the military business. Military vocabulary is a transitional phenomenon between the military terminology and the common vocabulary [1, p. 11].

There are such ways of military terms forming: affixation (rocketeer), compounding (warhead), conversion (to mortar), abbreviations (copter, ROAD - Retired on Active Duty, EAGLE - Elevation Angle Guidance Landing Equipment), transfer values (Diesel), changes values (acquisition), extension of value (to land), narrowing the meaning (cruiser), borrowing from other areas of science and technology (pin, strut), from other languages (bunker). In the language of military documents there is a special military phraseology shift-resistant and stable phrases that are infrequent used in the literary language and available in the field of language communication on military subjects. For example, shiftresistant combinations (to lift fire), coded stable combinations result from a hidden control of troops (mayday), command (general alarm), military aphorisms, proverbs, slang, vulgarisms (be quick on the draw - instantly respond, have sand in one's hair - to have experience of fighting in the desert) [2] .

Military terminology, as well as terminology of any one another branch of science and practice, belongs to the peripheral layers vocabulary of a particular language. However, it differs from other terminology because it has common features with a basic vocabulary. This is explained by the fact that many people are constantly involved in the military sphere, therefore, military terminology has compared with the terminology of other special areas of the broader scope of use [3, p. 137]. In addition, the conceptual system of military science tends to be permanent due to the close connection of military affairs with production. Continuous development and updating of combat types techniques dictate a change in the way of fighting that leads to a change in certain existing tactical concepts. The military-technical terminology, which manifests itself in changing the values of a 
number of terms in the termination of one terms and the appearance of others, reflects all changes in military affairs, as well as in armament and military equipment

The main groups of military vocabulary are:

1) military terminology, denoting concepts that are directly related to military affairs, armed forces, methods of warfare, etc.;

2) military-technical terminology, which includes scientific and technical terms; and emotionally colored military vocabulary (slang), represented by words and combinations that are often used by military personnel and are in fact stylistic synonyms of the respective military terms.

The correct translation of military materials depends greatly from the correct translation of terms, since military and military-technical terms bearing maximum meaning takes up most of the military vocabulary. Moreover, one of the most important problems in achieving translation adequacy is original style. The stylistic aspect of the translation is the correct choice of lexical and grammatical means in accordance with common functional and communicative orientation of the source text and taking into account the existing literary norms of the target language. The style of war materials is not uniform.

There are two trends of the war materials presentation: 1) either dry official language using cumbersome, often archaic turns or designs; 2) simple, colloquial, sometimes familiar language. The latest trend is mainly presented in military and military-technical materials, designed for private and non-officer staff. This trend primarily relates to low level of general and technical training, and consequently, with the desire to make dry official statutory materials and difficult technical manuals more popular and accessible to the majority of military personnel. Because of this, many military materials abound explanatory illustrations, tables, and diagrams, helping to bring to the reader the essence of the question. In all cases translator must strive to transmit the original material, using the English military style of presentation of relevant materials. The style of presentation in English must comply with the norms of the English military language adopted for the relevant type of material.

The practice of translation, including the military translation, is inconceivable without deep knowledge of the theory and comprehension of the complexity of the translation process $[4$, p. 79]. There are two main groups of translation transformations: lexical and grammatical, and one complex group lexical-grammatical. Lexical transformations unite receptions for transcription and transliteration, calculation and lexical-semantic substitutions (concretization, generalization, modulation). Grammatical transformations combine syntactic techniques approximations (verbal translation), division of sentence, combining sentences, grammatical substitutions (word forms, parts of speech, member of the sentence). Lexical-grammatical transformations - antonymic translation, explication (descriptive transfer) and compensation [5, p. 192]. Allocated by L. S. Barhudarov addition and omission, as well as cases of compression, we assigned to lexical-semantic substitutions of one or another kind [6, p. 101]. In addition, in some cases the Englishspeaking military terms have consistent correspondences in the Ukrainian language that do not have coincidences in the semantics of its components. Inexperienced translator of the military texts may allow mistakes in the translation of terms, which coincide in form (pronunciation, writing, word-formative structure), but differ in meaning and use [7, p. 114].

From the point of view of the difficulty of understanding and translation of the military terms, it is possible to subdivide them into three groups [8, p. 160]:

1. Terms denoting the realities of Ukrainian reality, for example, field hospital польовий госпіталь, chief of staff - начальник итабу, recoil brake - гальмо відкату. Understanding and translating the terms of this group does not pose any particular difficulties.

The following cases of translation are possible: 
a) As an equivalent. The Ukrainian term is used, the form of which is associated with form of the English term (so-called international terms). For example, army - армія, division-дивізія, general-генерал.

b) As an equivalent. The Ukrainian term is used, the form of which does not relate to the form of English term. For example, rifle - гвинтівка, сотрапу - рота.

c) Multicomponent Ukrainian term consisting of several words, the components of which coincide in form and values with the corresponding components of the English term. For example, antitank artillery - протитанкова артилерія.

d) The total value of the multi-component English term fully coincides with the same Ukrainian term, but its individual components are different from the components of the Ukrainian equivalent. For example: field equipment - похідне спорядження, flame thrower - вогнемет, mine detector - міношукач.

2. Terms, that denote English realities are absent in Ukrainian reality, but have generally accepted Ukrainian terminological equivalents. For example, Air National Guard - національна гвардія ВВС, Territorial Army - територіальна армія, headquarters and headquarters company - штаб і штабна рота. Great importance in translation of the terms of this group is the context that allows output the total value of a term from the values of its components [9].

3. Terms that denote the English realities, which are absent in Ukrainian reality and do not have commonly accepted Ukrainian terminological equivalents. The translation of these terms is the biggest difficulty since it is correct translation cannot be done without careful, sometimes even etymological analysis of its components. Usually we achieve the translation of this group of terms due to:

a) verbal translation, for example, general staff - спільний штаб, first lieutenant периий лейтенант;

b) partial or full transliteration, for example, master sergeant-майстерсержант,

c) transliteration and verbal translation, for example, chief master sergeant - головний майстер-сержант;

d) transcription, for example, ensign - енсін, captain - кептен, commander командер.

It should be noted that the main mistake in translation of such terms is that translators sometimes seek to find a literal match of the foreign term to Ukrainian terms. Such an approach is not entirely correct, because, firstly, the specifics of the realities of the foreign army are erased, and secondly, there may be an error in the fact that these terms may express the notions specific to these armies, and so do not correspond to the realities adopted in the Ukrainian army.

Another mistake of the translator is the literal translation, when the English term or its components is similar to the Ukrainian term, but have another meaning. For example, the term general staff should we translate as a спільний штаб оr загальна частина штабу, but not а генеральний штаб, because the notion of the general staff has nothing to do with the concept of general staff. The term military academy it is correctly to translate as військовий коледж, not військова академія. While translating, you should also always take into account the actual meaning of the term in a particular context, in this context. For example, the term battalion does not mean батальйон в піхоті, but дивізіон в артилерії. It should also take into account the possible shift of the value of the term when using the plural. For example, defense means оборона, defenses - оборонні споруди; store - запас, склад, магазин; stores - майно, вантажі, матеріальні кошти.

Formal as well as general functional correspondence is very important in a certain stylistic plan. Compliance with the formal correspondence does not create correct stylistic conformity, but rather destroys it during the translation process. In the translation practice, the following concepts are used: "meaningful distortion", "content loss", "stylistic mismatch", or "stylistic neutralization," "the use of wrong equivalents," and others.

The number of possible errors is particularly great when we translate innovative lexical units. However, the translator will greatly reduce the error if he/she adheres to a non-violent 
condition: an understanding of the actual situation underlying the text, the knowledge of reality itself, which is referred to in the text $[10$, p. 33]. The overcoming of subjectivity and error in translation can be done simultaneously and independently when a group of translators evaluates the translation, compares translation options. In this case lexicographic sources have great importance: dictionaries, textbooks and manuals that would reveal the connotative and denotative meanings of words, their origin, and possible means of translation.

Conclusions: Military terminology is rich in the variety of used terms. Any term has its own peculiarities, structural diversity, and emotional aspect and belongs to a particular sphere of life. Terms are constantly gaining new shades and meanings so that it complicates the work of the translator. Some terms become fixed and comprise a basic vocabulary, and part of them disappears. A large number of words, which are neutral themselves, acquire the properties of evaluation in the military language. We have found out that in the translation of military terminology, the translator can apply different methods of translation, which allow transferring the speaker's relation to military situation and expressing his or her opinion. First of all, the translator should know and use different types of translation transformations. Among these types are transcription, transliteration, tracing, and removing.

The stylistic aspect of the translation is the correct selection of lexicographical features in accordance with the overall functional and communicative orientation of the source text, taking into account the existing literary norms of the target language. Military texts functioning within media discourse have the conciseness, clarity and specificity of the wording, the accuracy and clarity of the presentation, which provides a logical sequence of presentation, a clear separation of one thought from another, the ease of perception of the transmitted information. The correct translation of military material depends on the correct translation of terms, since military technical terms with maximum semantic load takes most military vocabulary.

\title{
СТРАТЕГІЇ ПЕРЕКЛАДУ УКРАЇНСЬКОЇ МІЛІТАРНОЇ ТЕРМІНОЛОГЇ НА ОСНОВІ АНГЛОМОВНОГО МЕДІА ДИСКУРСУ
}

\author{
А. В. Прокопенко, канд. філол. наук, ст. викладач; \\ I. Чуприна, студентка \\ Сумський державний університет, \\ вул. Римського-Корсакова, 2, м. Суми, 40007, Україна \\ E-mail: a.prokopenko@gf.sumdu.edu.ua; irinacuprina17@gmail.com
}

Стаття присвячена перекладу української військової термінології на основі англомовного медіа дискурсу. Військова субмова, що продовжує існувати у певний історичний період держави, одночасно підпорядковується законам еволючійного розвитку. Ї̈ ядро, тобто термінологія та периферія, щчо поповнюються «неологізмами», або ж словами-фразеологізмами, з'явилися на певному етапі розвитку військової субмови для передачі нових військових реалій та концепиій. Відмінною рисою військового перекладу є надмірна термінологічність і гранично точне, чітке викладення матеріалу при відносній відсутності емочійних засобів виразності. У військовому перекладі дуже велике значення має точність перекладу, оскільки матеріал, який був перекладений, може служити основою для прийняття важливих рімень і проведення військових операчій. Тому адекватність перекладу військових матеріалів передбачає не тільки точну передачу змісту матеріалу, але і більи ретельну передачу його структурної форми, порядку частин, послідовності викладу і низка інших факторів, які можуть здаватися непотрібними, формальними, але мають велике значення для військового фахівия. Досвід активної співпраці України з іншими країнами в межах миротворчої діяльності ООН свідчить, щяо в умовах міжкультурної комунікацї переклад як засіб спілкування на всіх рівнях співробітництва набуває особливої значущості. Під час вивчення текстів медіа дискурсу було встановлено, щио вибір методу перекладу військової термінології безпосередньо залежить від структури самого терміну. Результати дослідження показують, що найбільи потиреними та популярними методами перекладу простих та багатокомпонентних (складних) термінів є лексичні та семантичні заміни, описовий переклад та калькування. У процесі перекладу абревіацій найбільш часто використовуваними призмами є переклад повної форми, а також семантичні заміни, транскрипція та транслітерація.

Ключові слова: військова термінологія, описовий переклад, скорочення, транскрипція, транслітерація, заміщення. 


\title{
СТРАТЕГИИ ПЕРЕВОДА УКРАИНСКОЙ МИЛИТАРНОЙ ТЕРМИНОЛОГИИ НА ОСНОВЕ АНГЛОЯЗЫЧНОГО МЕДИА ДИСКУРСА
}

\author{
А. В. Прокопенко, канд. филол. наук, ст. преподаватель; \\ И. Чуприна, студентка \\ Сумский государственный университет, \\ ул. Римского-Корсакова, 2, г. Сумы, 40007, Украина \\ E-mail: a.prokopenko@gf.sumdu.edu.ua; irinacuprina17@gmail.com
}

Статья посвящена переводу украинской военной терминологии на основе англоязычного медиа дискурса. Военный, который продолжает существовать в определенный исторический период государства, одновременно подчиняется законам эволючионного развития. Его ядро, то есть терминология и периферия, пополняемые «неологизмами», или же словам, фразеологизмами, появились на определенном этапе развития военного субъязыка для передачи новых военных реалий и концепций. При изучении журналистских текстов было определено, что выбор метода перевода военной терминологии напрямую зависит от структуры самого термина. Результаты исследования показывают, что наиболее распространенными $и$ популярными методами перевода простых и многокомпонентных (сложных) терминов являются лексические и семантические замены, описательный перевод и калькирование. В прочессе перевода аббревиачий наиболее часто используемыми призмами является перевод полной формы, а также семантические замены, транскрипция и транслитерация.

Ключевые слова: военная терминология, описательный перевод, сокращение, транскрипция, транслитерация, замещения.

\section{СПИСОК ВИКОРИСТАНИХ ДЖЕРЕЛ}

1. Общая терминология: вопросы теории / [Суперанская А. В., Подольская Н. В., Васильева Н. В. Москва, 2003. - 248 с.

2. Military Jargon Database [Electronic resource]. - Access mode: http://www.jargondatabase.com/category/military - (21.10.2018).

3. Онуфрієнко Г. С. Україномовна військова термінолексика: сучасний стан і проблеми перекладу / Г. С. Онуфрієнко // Проблеми української науково-технічної термінології. - Львів, 1996. - 138 с.

4. Стрелковский Г. М. Теория и практика военного перевода. Немецкий язык / Г. М. Стрелковский. Москва : Воениздат, 1979. - 272 с.

5. Комиссаров В. Н. Теория перевода (лингвистические аспекты) : учеб. для ин-тов и фак. иностр. яз. / В. Н. Комиссаров. - Москва : Высшая школа, 1990. - 253 с.

6. Драко М. В. Чтение и перевод английской научной и технической литературы: Лексика, грамматика, фонетика, упражнения / М. В. Драко. - Минск : ООО «Попурри», 1997. - 608 с.

7. Нелюбин Л. Л. Введение в технику перевода / Л. Л. Нелюбин. - Москва : Издательство «Флинта», 2012. $-216 \mathrm{c}$

8. Латышев Л. К. Перевод: проблемы, теории, практики и методики преподавания / Л. К. Латышев. Москва : Просвещение, 1988. - 160 с.

9. Glossary of Military Terms \& Slang from the Vietnam War [Electronic resource]. - Access mode: http://www2.iath.virginia.edu/sixties/HTML - (30.10.2018).

10. Бархударов Л. С. Язык и перевод / Л. С. Бархударов. - Москва : Издательство ЛКИ, 2010. - 240 с.

\section{REFERENCES}

1. Superanskaya A. V., Podolskaya N. V., Vasileva N. V. Obschaya terminologiya: voprosyi teorii. Moscow, 2003. $248 \mathrm{~s}$.

2. Military Jargon Database. - Access mode: http://www.jargondatabase.com/category/military - (21.10.2018).

3. Onufrienko G. S. ukrayinomovna viyskova terminoleksika: suchasniy stan i problemi perekladu. Problemi ukrayinskoyi naukovo-tehnichnoyi terminologiyi. Lviv, 1996. $138 \mathrm{~s}$.

4. Strelkovskiy G. M. Teoriya i praktika voennogo perevoda. Nemetskiy yazyik. Moscow : Voenizdat, 1979. 272

5. Komissarov V. N. Teoriya perevoda (lingvisticheskie aspektyi). Moscow : Vyisshaya shkola, 1990. $253 \mathrm{~s}$

6. Drako M. V. Chtenie i perevod angliyskoy nauchnoy i tehnicheskoy literaturyi: Leksika, grammatika, fonetika, uprazhneniya. Minsk, 1997. $608 \mathrm{~s}$.

7. Nelyubin L. L. Vvedenie v tehniku perevoda. Moscow : Flinta, 2012. $216 \mathrm{~s}$.

8. Latyishev L. K. Perevod: problemyi, teorii, praktiki i metodiki prepodavaniya. Moscow : Prosveschenie, 1988. $160 \mathrm{~s}$.

9. Glossary of Military Terms \& Slang from the Vietnam War. - Access mode: http://www2.iath.virginia.edu/sixties/HTML - (30.10.2018).

10. Barhudarov L. S. Yazyik i perevod. Moscow : Izdatelstvo LKI, 2010. $240 \mathrm{~s}$

Received: 2 November, 2018 